\title{
Enhancement of Palm residues (Phoenix canariensis) for a potential use in ruminant feed
}

\author{
G. Sperandio,, M. Fedrizzi, ${ }^{1}$ M. lacurto, ${ }^{2}$ F. Vincenti, ${ }^{2}$ M. Guerrieri,, ${ }^{1}$ D. Pochi, ${ }^{1}$ R. Fanigliulo, ${ }^{1}$ \\ M. Pagano, ${ }^{1}$
}

\author{
'CRA-ING, Consiglio per la Ricerca e la Sperimentazione in Agricoltura, Unità di ricerca per \\ I'ingegneriaagraria, Monterotondo (Roma), Italy; ${ }^{2}$ CRA-PCM, Consiglio per la Ricerca e la \\ Sperimentazione in Agricoltura, Centro di ricerca per la produzione delle carni e il miglioramento \\ genetico, Monterotondo scalo (Roma), Italy
}

\begin{abstract}
The increase of biological residues from numerous fellings of palms (Phoenix canariensis) infested by red palm weevil (Rhynchophorus ferrugineus Olivier) in central Italy and around the Mediterranean basin, has created an important disposal problem. This issue could provide a further use by introducing it as a food in diet of ruminants, beyond that represented by the use as fuel in biomass power plants for heating or electrical energy. The shredded material of palm can be employed to animal nutrition, resulting in interest for the feed industry and livestock sector. Analysis, carried out on samples of shredded palm, made using a chipper machine modified to obtain a product of small size (according to the phytosanitary measures of Lazio Region: n. 390, June 5, 2007), showed an high water content (79\%) and therefore a not easy conservation. A conservation technique could be dehydration, in order to make product as flour, pellets, to introduce in unifeed together with the other compounds of the diet (forage, concentrates, etc.). Given the high water content, the dehydration process causes a very high production cost.

About nutritional value, analysis showed $0.65 \mathrm{UF} / \mathrm{kg}$ on dry matter basis, higher than the straw and hay of stable grass in an advanced stage of maturation ( 0.20 to $0.30 \mathrm{UF} / \mathrm{kg}$ ). These values are similar to a good hay obtained from mixed grass. As consequence it is possible to use shredded palm as part of energy of the ruminants diet. Is still not
\end{abstract}

Correspondence: Mauro Pagano, Consiglio per la Ricerca e la Sperimentazione in Agricoltura, Unità di ricerca per l'ingegneria agraria (CRA-ING), Via della Pascolare, 15- 00016 - Monterotondo (Roma), Italy.

Tel.: +39.06 90675253 - Fax: +39.06 90625591

E-mail: mauro.pagano@entecra.it

Key words: feed, palm, biological residues, Rhynchophorus ferrugineus.

Contributions: the authors contributed equally.

Conflict of interests: the authors declare no potential conflict of interests.

(C) Copyright G. Sperandio et al., 2013

Licensee PAGEPress, Italy

Journal of Agricultural Engineering 2013; XLIV(s2):e127

doi:10.4081/jae.2013.s2.e127

This article is distributed under the terms of the Creative Commons Attribution Noncommercial License (by-nc 3.0) which permits any noncommercial use, distribution, and reproduction in any medium, provided the original author(s) and source are credited. clear which component allows the achievement of this value, probably derives in small part by the lipid component and largely by the fibrous component. Moreover data showed that the presence of fatty acid precursors of CLA (Conjugated Linoleic Acid) such as oleic acid and linoleic acid, is much higher than the values of Italian pastures. Utilization of these fatty acids in animal diets improves quality of the final products (milk, cheese, meat). The possibility of introducing shredded palm in ruminants diet, may be topic of interested to feed animal in arid areas of the Mediterranean basin, where it is difficult to find good forages.

\section{Introduction}

The epidemic diffusion of the Red Palm Weevil (Rhynchophorus ferrugineus Olivier, 1790), now configured as a real biological invasion, has been exacerbated by the difficulties of disposing of many palm trees torn down and the difficulty of being able to retrieve the necessary material for alternative purposes, considering the high cost of logistics management of such biomass. Is therefore increasingly necessary to implement actions recovery and enhancement of material in compliance with current legislation in the phytosanitary field, implementing specific actions to prevent the diffusion of RWP also in later stages of disposal. In this context, you can insert the action of palm wood shredded reduction, through the use of machines properly prepared to exterminate the phytophagous insect and then be able to avoid the insect reproduction. We describe the actions taken and the means employed for the palms shredded reduction, suggesting a possible re-use of the obtained product as a food supplement in the ruminants diet. The main problem of shredded palm is the water content that is about $79 \%$. A normal corn silage presents a water content between $65 \%$ to $70 \%$, depending on harvest time. Different values are reported for cornstalks (values close to 20\%); hay (values from $15 \%$ to $20 \%$ ) and wheat straw (values close to 10\%). As a consequence of the high water content is very difficult to conserve shredded palm, the best method to conserve could be the ensilage process, but the very low carbohydrate content $(9.30 \mathrm{~g} / 100 \mathrm{~g})$ causes a low availability of fermentable sugar, needed for a proper acidification of the silage. To solve this problem, it could be hypothesized the addition of sugars during ensiling, in order to guarantee a correct preservation process. Another technique of preservation, may be the dehydration that allows use as flour, pellets, in Total Mixed Ration (TMR) preparation, together with the other compounds (fodder, concentrated, etc.). The process of dehydration could have a very high cost considering the high water content of the product. 


\section{Materials and methods}

IIn November 2012 at Engineering Research Unit of the Agricultural Research Council (CRA-ING) in Monterotondo (Rome), were conducted the first tests of the palm wood shredded reduction with mechanical shredding action. Have been used a portions of stems and leaves of palm trees (Phoenix canariensis) torn down because it was found that in our country are these to be most affected by the phytophagous insect RPW (Griffo, 2010). In order to conduct the test we used a shredding machine made by FARMI, model FOREST CH 260 . From the obtained material (shredded) were taken samples of the product for which were to determine some basic parameters: density, moisture content and size fractions (particle size analysis of the sample of palm wood chips) to European standard established by CEN(European Committee for Standardization). Parallel with other samples of material (placed in polyethylene bags packed in vacuum average weight $2.5 \mathrm{~kg}$ ) were sent to the laboratories of the Research Centre for meat production and genetic improvement of the Agricultural Research Council (CRA-CPM) Monterotondo (Rome), to carry the appropriate chemical analysis, with the purpose of being able to know the nutritional aspects in the animals diets.

The machine made by FARMI, model FOREST CH-260, is a forestry chipper machine constituted by a rotor disc cutter, with the possibility to adjust the average size of the wood chips to ensure the right size and homogeneity of the product (Fig. 1). The rotor carries out $1.000 \mathrm{rpm}$ max., with a $1050 \mathrm{~mm}$ of diameter and $240 \mathrm{~kg}$ of weigh. For the chipper has been eliminated the screening grid to prevent clogging of the machine caused by the fibrous palm wood that adheres at inner walls of the machine (Fig. 1).

The chipper machine has been driven by a tractor with $100 \mathrm{~kW}$ of power, is connected to it by means of a cardan shaft. The power supply system is hydraulic and composed of two spiked rollers: the upper roller, of greater diameter mounted on a mobile frame compressed by a spring to maintain adherence with the input material to be chipped, ensuring an efficient power and the high productivity result.

The chipping is done primarily through knives mounted on recordable media, attached to the rotor by means of screws. More branches cutting blades mounted inside the housing of the chipper in conjunction with the specific comb rotor perform a secondary processing of wood chips. The maximum diameter of the stems that can be introduced into the machine is about $260 \mathrm{~mm}$, so the stems of palm trees have been previously divided into pieces of smaller sizes through the use of the chainsaw. Using the described chipper machine is possible to obtain chips with average size between 7.00 and $25.00 \mathrm{~mm}$. The material obtained was ejected through a launch tube into a trailer (Fig. 3 ).

\section{Chipper machine and yard work description}

The machine made by FARMI, model FOREST CH-260, is a forestry chipper machine constituted by a rotor disc cutter, with the possibility to adjust the average size of the wood chips to ensure the right size and homogeneity of the product (Fig. 1). The rotor carries out $1.000 \mathrm{rpm}$ max., with a $1050 \mathrm{~mm}$ of diameter and $240 \mathrm{~kg}$ of weigh. For the chipper has been eliminated the screening grid to prevent clogging of the machine caused by the fibrous palm wood that adheres at inner walls of the machine (Fig. 1).

The chipper machine has been driven by a tractor with $100 \mathrm{~kW}$ of power, is connected to it by means of a cardan shaft. The power supply system is hydraulic and composed of two spiked rollers: the upper roller, of greater diameter mounted on a mobile frame compressed by a spring to maintain adherence with the input material to be chipped, ensuring an efficient power and the high productivity result.

The chipping is done primarily through knives mounted on recordable media, attached to the rotor by means of screws. More branches cutting blades mounted inside the housing of the chipper in conjunction with the specific comb rotor perform a secondary processing of wood chips. The maximum diameter of the stems that can be introduced into the machine is about $260 \mathrm{~mm}$, so the stems of palm trees have been previously divided into pieces of smaller sizes through the use of the chainsaw. Using the described chipper machine is possible to obtain chips with average size between 7.00 and $25.00 \mathrm{~mm}$. The material obtained was ejected through a launch tube into a trailer (Fig. 3 ).

\section{Nutritional aspects: energy content}

The energy value, reported as $0.65 \mathrm{UF} / \mathrm{kg}$, was higher than the value of straw and hay of permanent grass harvest in an advanced stage of maturity (0.20-0.30 UF/kg), and it was similar to hay. As consequence of these values it is possible to use this product as part of energy in ruminants diet. Probably the energy value is represented in small part

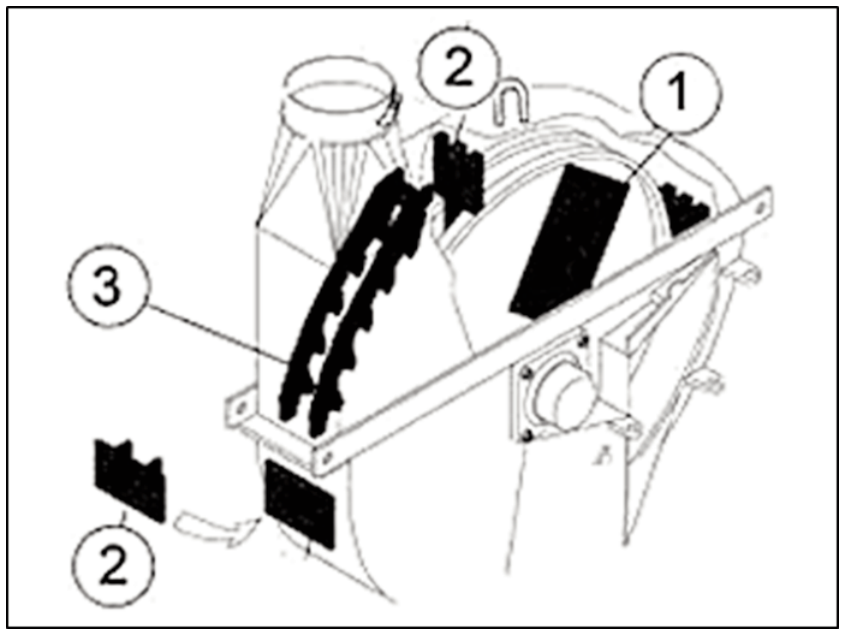

Figure 1. Chipping in 3 stages (for wood chips basis): 1 . Double knife on the rotor disk 2. Fixed knives 3. Final knives. (source: http://www.deangeli.bz.it)

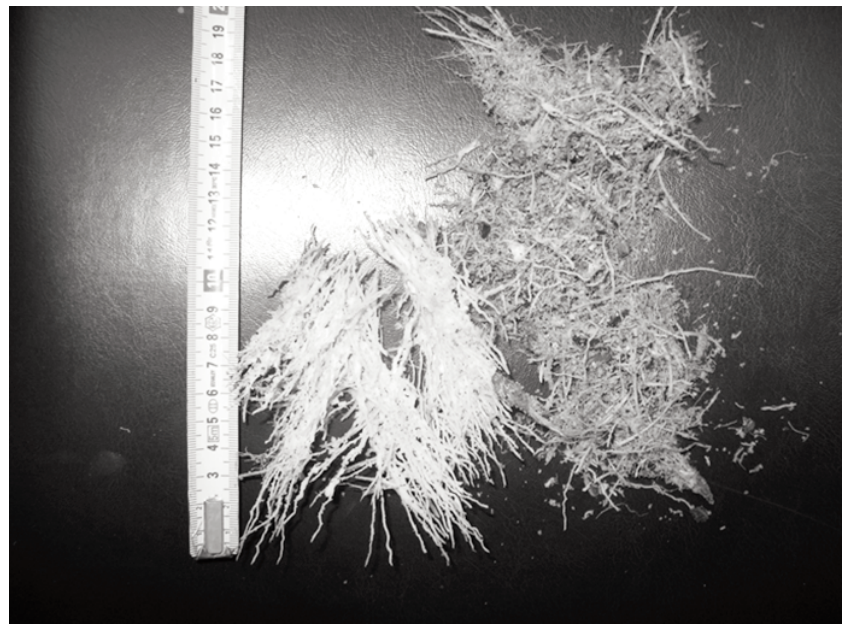

Figure 2. Characteristics fibrous palm wood 

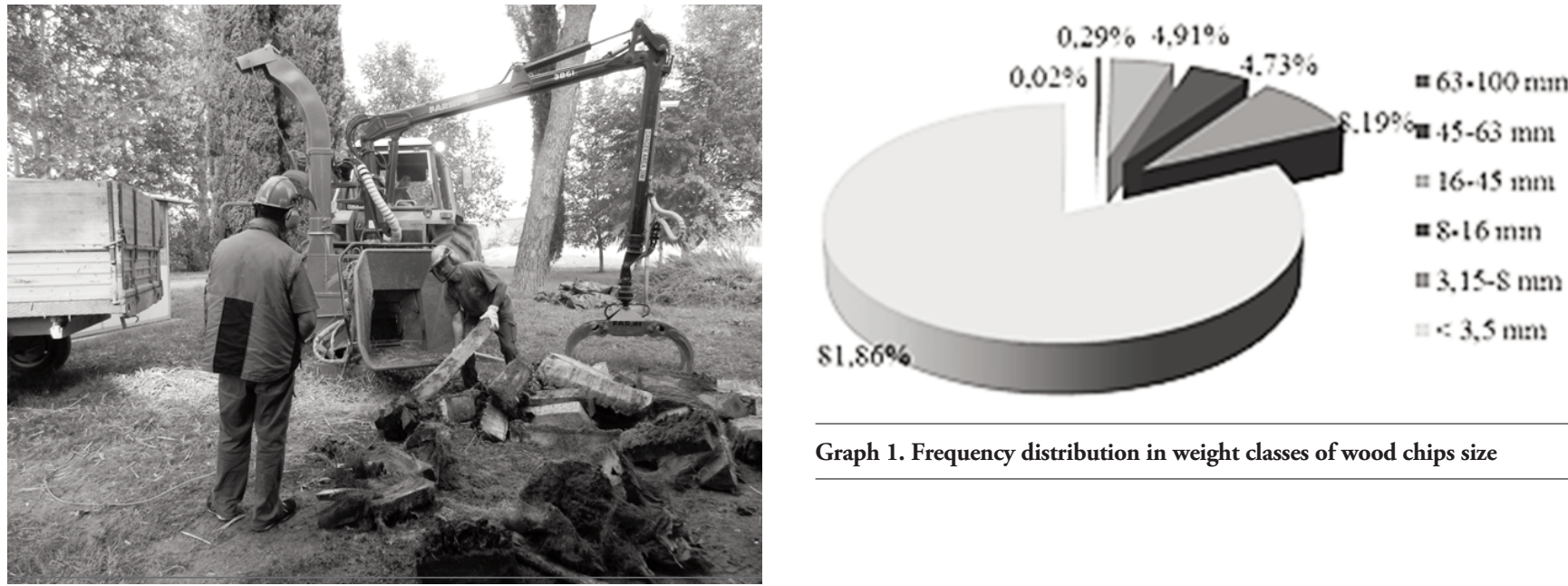

Graph 1. Frequency distribution in weight classes of wood chips size

Figure 3. The wood chipper FARMI model - CH260 FOREST at work

Table 1. Daily requirements of minerals and vtamine in bovine growth. (source: www.iis-calvi.com)

\begin{tabular}{|c|c|c|c|c|c|c|c|c|c|}
\hline $\begin{array}{l}\text { Live weight } \\
\text { (kg) }\end{array}$ & $\begin{array}{l}\text { Growth } \\
(\mathrm{g} / \mathrm{d})\end{array}$ & $\begin{array}{l}\mathrm{Ca} \\
(\mathrm{g})\end{array}$ & $\begin{array}{l}P \\
(g)\end{array}$ & $\begin{array}{l}\mathrm{Mg} \\
(\mathrm{g})\end{array}$ & $\begin{array}{l}\mathrm{K} \\
(\mathrm{g})\end{array}$ & $\begin{array}{l}\mathrm{Na} \\
(\mathrm{g})\end{array}$ & $\begin{array}{l}\mathrm{Cl} \\
(\mathrm{g})\end{array}$ & $\begin{array}{l}\text { A -Vitamins } \\
\text { (U. I.) }\end{array}$ & $\begin{array}{c}\text { D - Vitamins } \\
\text { (U. I.) }\end{array}$ \\
\hline \multirow[t]{2}{*}{150} & 1000 & 27 & 15 & 1.9 & & & & & \\
\hline & 1400 & 37 & 19 & 2.2 & 11 & 4.0 & 5.0 & 10.000 & 1.000 \\
\hline \multirow[t]{2}{*}{250} & 1000 & 34 & 21 & 3.3 & & & & & \\
\hline & 1400 & 44 & 24 & 3.9 & 17 & 6.0 & 7.0 & 15.000 & 1.500 \\
\hline \multirow[t]{2}{*}{350} & 1000 & 42 & 35 & 5.2 & & & & & \\
\hline & 1400 & 53 & 33 & 5.4 & 23 & 7.0 & 10.0 & 22.000 & 2.300 \\
\hline \multirow[t]{2}{*}{450} & 1000 & 52 & 38 & 6.8 & & & & & \\
\hline & 1400 & 64 & 35 & 7.6 & 29 & 8.5 & 12.5 & 28.000 & 2.900 \\
\hline \multirow[t]{2}{*}{550} & 1000 & 57 & 39 & 7.9 & & & & & \\
\hline & 1200 & 68 & 37 & 8.8 & 35 & 10.5 & 16.0 & 35.000 & 3.500 \\
\hline \multirow[t]{2}{*}{650} & 1000 & 62 & 37 & 8.9 & & & & & \\
\hline & 1200 & 72 & 40 & 9.9 & 41 & 11.5 & 19.5 & 41.000 & 4.100 \\
\hline
\end{tabular}

from the lipid component, and largely by the fibrous component of the product. Nevertheless the quality of the fiber present appears to be anomalous. Values of NDF (14.68) are different from the values recorded in the wheat straw (70-75), cornstalks (65-70), hay (60-65) and corn silage (43-45). The same situation was recorded with regard to ADF content, the value of 10.81 was different from the corn silage (30-35), hay and cornstalks (40-45)and wheat straw (50). Therefore, this product seems to have a very digestible fiber, but not so good in terms of functionality and anatomical development of rumen, these aspects may generate an excessive speed of diet transit, resulting in a poor assimilation diet components.

\section{Protein content}

Certainly cannot be considered a protein food, in fact proteins content were $0.840 \mathrm{~g} / 100 \mathrm{~g}(0.8 \% \mathrm{~kg} / \mathrm{ss})$ very different from wheat straw (usually not used as protein food ( $\mathrm{PG}=3.7 \% / \mathrm{kg} \mathrm{DM})$ ) or not good ryegrass hay where we reach values close to $2.5 \% \mathrm{~kg} / \mathrm{S} . \mathrm{S}$.

\section{Fatty acid composition}

Regarding the fatty acid composition, there was a very high level of palmitic acid. The levels of fatty acid precursors of CLA were high, in particular levels of oleic acid (18.16\%) and linoleic acid (15.89\%). Linolenic acid content was not good (1.55\%). The values of Oleic and Linoleic were higher than the values recorded by Italian pastures where these values are $2.05 \%$ about oleic acid and $10.57 \%$ about linoleic acid.

\section{Minerals}

Regarding the minerals, in particular about those that might cause problems for animal health, was recorded low Zinc content $(9 \mathrm{mg} / \mathrm{kg})$, according to European Union Reg. 1334/03 where for ruminants are reported tolerance limits $20-65 \mathrm{mg} / \mathrm{kg}$. Lead content $(0.15 \mathrm{mg} / \mathrm{kg})$ was much lower than those reported by European Union Reg. 744/2012, where are reported tolerance limits from $5 \mathrm{mg} / \mathrm{kg}$ to $30 \mathrm{mg} / \mathrm{kg}$, depending on the raw material used.

The only trace elements with a good levels were Calcium (54.3 $\mathrm{mg} / 100 \mathrm{~g}$ ), Phosphorus (53 mg/100 g), Sodium (238 mg/100 g) and Potassium ( $227 \mathrm{mg} / 100 \mathrm{~g})$. The levels of these elements might suggest to use as a mineral supplement in the diets of dairy and beef cattle. 


\section{Results}

The first tests results, show that the material produced meets the requirements of the current legislation at national and regional level. It would therefore be conceivable to enhance the product, assigning it to a direct use in livestock farms. The work carried out by the chipper machine, resulted in the need to further cut of palm trees leading to other costs.

The various size classes different iation shows that over $90 \%$ of the sample falls within a range between 3.5 and $16 \mathrm{~mm}$. (Graph 1). In total have been produced about $910 \mathrm{~kg}$ of material crushed to $75,87 \%$ of water content representing approximately 1.5 palm trees. As shown in Graph 1, 81.86\% showed dimensions of less than $3.5 \mathrm{~mm}$ and only $5.22 \%$ of the sample falls within a range between $16 \mathrm{~mm}$ and $100 \mathrm{~mm}$, while the $0.31 \%$ is between $45 \mathrm{~mm}$ and $100 \mathrm{~mm}$.

\section{Conclusion}

In conclusion it is possible to say that the wood chips of palm tree is difficult to use in ruminants diet. First of all, it appears a problem of preservation, due to the high water content. In addition, the chemical analysis showed a very poor nutritional values, in particular respect to protein content. As already mentioned previously, may be used as mineral integration or as energy part of the diet. Regard to the work quality, referring to mechanical shredding operations of palm wood, it highlights the need to intervene with further cuts for the size reducing of the palm stems. This operation increases the whole cost of the shredding.

\section{References}

1. P.F. Roversi, 2013, http://sito.entecra.it/portale/cra_progetti. http://www.iis-calvi.com ; http://www.deangeli.bz.it 